\title{
PROFIL DEPRESI PADA GURU - GURU SD DI KECAMATAN WORI MANADO
}

\author{
Lisbeth F. J. Kandou \\ Bagian Kedokteran Jiwa Fakultas Kedokteran Universitas Sam Ratulangi Manado
}

\begin{abstract}
Depression usually occurs in daily life. It appears as sadness and loss of interest for things that were enjoyable in the past. There are many causes of depression, e.g. work overload, stressful work, or lack of self confidence. Depression can be found in all ages and jobs, including teaching. Management of depression consists of pharmacotherapy by using antidepressant drugs and psychotherapy. The purpose of this study was to find out whether there was depression among elementary school teachers in Wori Manado, and the degree and prevalence of depression. The methodology used was the cross-sectional method, involving 91 teachers of elementary schools in Wori Manado who filled in Hamilton Depression Rating Scale (HDRS) questionnaires. The results showed that 90 respondents (99\%) suffered varying degree of depression, depending on certain variable characteristics.
\end{abstract}

Keywords: depression, teacher

\begin{abstract}
Abstrak: Depresi sering dijumpai dalam kehidupan sehari-hari yang ditandai dengan sedih dan kehilangan minat akan hal-hal yang disenangi. Penyebab depresi cukup banyak, diantaranya: beban kerja yang meningkat, stress pada pekerjaan, kurang rasa percaya diri dan sebagainya Depresi dapat terjadi pada semua golongan usia dan pekerjaan, termasuk guru. ${ }^{1-5}$ Penatalaksanaan depresi mencakup farmakoterapi dengan menggunakan antidepresan dan psikoterapi. Tujuan penelitian: Mengetahui ada tidaknya depresi, derajat serta prevalensinya pada guru-guru SD di kecamatan Wori Manado. Metode: Penelitian menggunakan rancangan cross sectional yang melibatkan 91 responden guru-guru SD di Kecamatan Wori dengan mengisi kuesioner dari Hamilton Depression Rating Scale (HDRS) sebagai tolak ukurnya. Hasil: didapatkan bahwa 90 orang (99\%) guru SD menderita depresi dengan derajat yang berbeda-beda tergantung karakteristik variabel yang sudah ditentukan sebelumnya.
\end{abstract}

Kata kunci: depresi, guru

Depresi adalah suatu gangguan jiwa yang ditandai dengan perasaan sedih dan kehilangan minat akan hal-hal yang disenangi dan bisa disertai dengan gejala-gejala psikologik lainnya, gangguan somatik maupun gangguan psikomotor. Dalam kehidupan sehari-hari depresi bisa disebabkan oleh berbagai hal diantaranya adalah: hubungan pergaulan yang tidak harmonis, kedudukan sebagai orang tua, perceraian, anak-anak atau remaja yang meninggalkan rumah, kesulitan keuangan, gagal dalam pekerjaan, kekayaan/kemewahan, habis masa jabatan/ pensiun, usia lanjut, gangguan kesehatan, perampasan hak atau kematian anak. ${ }^{1-5}$

Penggolongan depresi dimulai dari depresi ringan sampai berat. Depresi dapat diderita oleh siapa saja tanpa memandang usia dan status, termasuk guru. Dalam buku Psychology in Education (penulis Sidney L. Pressey, Francis P. Robinson dan John E. Harrocks) sub topik "Kesejahteraan Kerja Guru" (The hygiene of work teacher) dikemukakan bahwa dari 5000 lebih guru yang menjawab kuesioner, 37\% merasa dihantui oleh ketakutan yang mempengaruhi tidur, mengajar dan kesejahteraan hidup mereka. Suatu studi lain terhadap 5000 guru menda- 
patkan bahwa $10 \%$ dari mereka mengalami kecemasan. Selanjutnya Pressey juga menulis bahwa sebagian besar guru yang telah lama bekerja mengalami penurunan kesehatan jasmani, mempunyai vitalitas hidup yang rendah, dan juga mengalami gangguan kronis. ${ }^{1,6,7}$

Simond PM (1941) dalam tulisannya: Problem faced by teachers (Journal of Educational Research) yang dikutip dari buku Supervision (penulis: Burton), melaporkan bahwa sumber masalah yang dihadapi oleh para guru adalah sebagai berikut: hubungan kekeluargaan $45 \%$, kehidupan mencintai $37 \%$, perasaan tidak cocok dan rasa harga diri kurang $36 \%$, kesehatan $26 \%$, kurang setia 23\%, masalah keuangan $22 \%$, kesulitan dalam menghadapi aturan yang terlalu keras $18 \%$, masalah yang berhubungan dengan kedudukan 12\%, kecenderungan untuk agresif $12 \%$, kesulitan dalam berteman dengan sejawat $11 \%$, dan persoalan pribadi $11 \%$

Dari hasil penelitian tersebut diatas ternyata banyak guru mengalami persoalan baik yang berhubungan dengan masalah pribadi maupun berhubungan dengan jabatan mereka. Semua ini merupakan sumber ketidaksejahteranya para guru tersebut. Jelasnya apabila depresi dikalangan guru tidak mendapat perhatian atau penanganan, maka akan berdampak luas, baik pada guru itu sendiri, keluarga, masyarakat dan bahkan lebih khususnya generasi muda. ${ }^{7}$

\section{DEFINISI DAN KLASIFIKASI}

Depresi adalah salah satu bentuk gangguan kejiwaan pada alam perasaan seseorang dengan gejala utama sedih, disertai gejala-gejala psikologik lainnya seperti murung, putus asa, apati, pesimisme, rasa tak berdaya, tak berguna, dan sebagainya, serta gangguan somatik maupun gangguan psikomotor dalam kurun waktu tertentu dan digolongkan kedalam gangguan jiwa afektif. ${ }^{8}$

Depresi perlu dibedakan dengan kesedihan biasa. Kedua hal ini dapat dibedakan secara kuantitatif dimana pada depresi episodenya lebih lama dan gejala lebih intensif dibandingkan kesedihan biasa. ${ }^{9}$

Klasifikasi gangguan depresi sangat bervariasi. Terdapat tiga jenis gangguan depresi yaitu ${ }^{10-12}$ :

1. Depresi neurotik: penderita tidak mengalami gangguan mental berat dan masih dapat mengenali dirinya maupun lingkungannya.

2. Depresi psikotik: identifikasi gangguan ini relatif jelas dimana perubahan mood terjadi sebelum berkembangnya halusinasi, waham, atau perilaku yang aneh/ bizarre.

3. Depresi terselubung (masked depression): pasien dengan depresi jenis ini mungkin hadir dengan gejala-gejala fisik sebagai topeng/selubung. Pada kasus demikian, keluhan-keluhan subyektif dan perubahan mood digantikan oleh keluhan-keluhan somatik yang banyak dan tidak sesuai dengan beratnya kelainan.

\section{ETIOLOGI}

Depresi merupakan sekelompok gangguan gangguan alam perasaan. Terdapat beberapa faktor yang diduga berpengaruh terhadap etiologi depresi. ${ }^{11-15}$

\section{Faktor genetik}

Bagaimana proses gen diwariskan dalam hal kecenderungan depresi belum diketahui secara pasti. Bila dalam satu keluarga salah satu orang tuanya menderita depresi, anaknya beresiko dua kali lipat; dan apabila kedua orang tuanya menderita depresi maka resiko untuk mendapat gangguan alam perasaan sebelum usia 18 tahun menjadi empat kali lipat. Pada kembar monozigot, $76 \%$ kembarannya akan mengalami gangguan afektif, sedangkan bila kembar dizigot hanya $19 \%$.

\section{Faktor neurobiologi}

Terganggunya regulator sistem monoamin-neurotransmitter, termasuk norepinefrin dan serotonin adalah unsur kunci pada teori ini. Dari observasi didapatkan bahwa anti depresan trisiklik dan inhibitor 
MAO meningkatkan norepinefrin pada reseptor adrenergik di daerah sentral yaitu di sistem limbik dan hipotalamus dengan menghambat re-uptake nya.

\section{Faktor organik}

Faktor organik yang dimaksud adalah gangguan fisik, gangguan neurobiologi, serta pengaruh obat-obatan tertentu seperti analgesik, narkotik, antihipertensi, hipnotik sedatif dan sebagainya.

\section{Faktor psikososial}

Yang termasuk disini antara lain kehilangan pasangan hidup, perpisahan dengan anggota keluarga, menurunnya taraf kesehatan, dan kehilangan rasa aman, kekuasaan atau kebebasan.

\section{Faktor kepribadian}

Kepribadian yang paling sering menyebabkan depresi yaitu kepribadian melankolis. Individu dengan kepribadian ini biasanya sensitif, mudah tersinggung, ingin sempurna, dan tak ingin disalahkan.

\section{GEJALA KLINIS}

Di negara berkembang atau pada pasien yang pendidikannya kurang, biasanya gejala depresi akan muncul dengan urutan sebagai berikut ${ }^{16}$ :

1. Gangguan tidur: insomnia (sulit masuk tidur, tidur dangkal), bangun dini hari, banyak mimpi.

2. Gangguan cemas (anxietas): dapat timbul gangguan-gangguan somatik seperti sakit kepala, sesak napas, gangguan saluran cerna, palpitasi dan berkeringat dingin.

3. Gangguan emosi: disforia (menarik diri dari lingkungan dan tidak mau bergaul) serta merasakan kesedihan tanpa sebab sepanjang hari; dan anhedonia (ketidak mampuan menikmati kesenangan dan kehilangan minat akan kesenangan sebelumnya).

\section{Stres dalam lingkungan kerja}

Stres dalam lingkungan kerja timbul apabila kebutuhan dasar individu ditempat kerjanya tidak terpenuhi. Tercapainya kepuasan kerja pada hakekatnya apabila telah terpenuhinya setiap kebutuhan yang di inginkan oleh setiap manusia. Maslow mengemukakan lima jenis kebutuhan dasar manusia dengan urutan penggolongan berdasarkan kekuatan potensi dan desakan urgensi yaitu : ${ }^{17}$

1. Pemenuhan kebutuhan dasar manusia yang bersifat fisik. Apabila kebutuhan ini terpenuhi maka kehidupan seseorang akan seimbang. Keseimbangan ini sangat berperan dalam ketenangan bekerja, yang mutlak diperlukan oleh seorang pendidik.

2. Kebutuhan akan keselamatan, keamanan, serta jaminan perlindungan dari ancaman yang membahayakan kelangsungan pekerjaan dan kehidupan (safety needs).

3. Kebutuhan untuk disukai, dicintai, bergaul, berkelompok, bermasyarakat, berbangsa dan bernegara (social needs)

4. Kebutuhan untuk memperoleh penghormatan, pujian, penghargaan, dan pengakuan (the needs for esteems).

5. Kebutuhan memperoleh kebanggaan, keagungan, kekaguman dan kemasyuran (the needs for self actualization).

Terpenuhinya keinginan atau kebutuhan manusia diharapkan dapat meningkatkan kinerja dan prestasi kerja. Dengan demikian pembinaan karir yang berorientasi pada halhal tersebut akan memberi motivasi untuk berprestasi pada para guru.

\section{Diagnosis}

Dalam menentukan gejala yang timbul pada depresi, kita harus mengamati dahulu hal-hal yang mungkin muncul dalam wawancara dengan pasien depresi.

Depresi dapat didiagnosis dengan menggunakan International Classification of Diagnostic (ICD) 10, Diagnostic and Statistical Manual (DSM) IV, atau Pedoman Penggolongan Diagnosis Gangguan Jiwa (PPDGJ) III. ${ }^{18,19,20}$

Di Indonesia, diagnosis depresi ditegak- 
kan dengan mengunakan PPDGJ III, yang merupakan rujukan dari DSM IV dan ICD 10. Selain itu juga dapat dipakai Hamilton Depression Rating Scale (HDRS): bila didapatkan skor $>7$ maka seseorang dapat dikatakan menderita depresi.

\section{PENATALAKSANAAN}

Tujuan penatalaksanaan depresi yaitu untuk meringankan gejala-gejala depresi, mengurangi kekambuhan, memperbaiki kualitas hidup, memperbaiki kesehatan secara medis dan menurunkan mortalitas.

\section{Farmakoterapi $^{11,12,15}$}

\section{Anti depresan trisiklik (ADT)}

Berfungsi untuk meningkatkan neurotransmiter dengan menghambat reuptake atau menghambat kerja pompa untuk reuptake neurotransmiter. Efek sampingnya seperti efek kardiotoksik, hipotensi postural, problem memori, efek antikolinergik (mulut kering, kebingungan, penglihatan kabur, retensi urin, konstipasi dan perburukan glaukoma).

\section{Antidepresan generasi kedua (Antide- presan Tetrasiklik)}

Mempunyai efek sedasi yang kuat, sedangkan efek antikolinergik dan kardiologik relatif lebih kecil. Diberikan pada pasien yang tidak tahan terhadap efek kardiologik (biasanya pada orang tua) dan sindrom depresi dengan gejala anxietas dan insomnia yang menonjol. Berhubung terdapatnya kemungkinan efek depresi sum-sum tulang, maka perlu pemantauan gambaran darah tepi pada tiga bulan pertama pemakaian obat.

\section{Monoamine oxidase (MAO) inhibitors}

Obat-obat golongan ini bekerja meningkatkan neurotransmiter dengan cara menghambat enzim MAO. Pemakaian golongan obat ini pada usia lanjut dibatasi yaitu hanya pada kasus-kasus fobia, gejala hipokondriakal atau histerikal.

\section{Selective Serotonin Reuptake Inhibitor (SSRI)}

Secara selektif menghambat re-uptake serotonin. Selain cukup efektif, golongan obat ini juga mempunyai efek samping kecil, aman dan karena umumnya penderita hanya meminumnya sekali sehari maka kepatuhannya akan lebih baik.

\section{Atypical}

Obat-obat golongan ini mempunyai efek samping antikolinergik dan hipotensi yang ringan, tetapi efek sedasinya cukup kuat. Salah satu contoh obat golongan ini adalah trazodone.

\section{Psikoterapi $^{21}$}

\section{Psikoanalisis}

Metode terapi ini bersifat individual, dan tidak bersifat keluarga. Psikoanalisis bertujuan menyelesaikan konflik internal dan eksternal individu dengan mengubah emosi dan idea penderita.

\section{Psikoterapi supportif}

Disini termasuk semua cara yang bertujuan menghilangkan pengaruh konflik emosional dan menuju ke adaptasi psikis yang adekuat

\section{Psikoterapi kognitif}

Metode terapi ini bertujuan untuk mengubah pola pikir negatif ke arah pola pikir yang netral/positif.

\section{Terapi keluarga}

Untuk mendapatkan hasil yang optimal, perlu dukungan keluarga maupun lingkungan agar penderita tidak pernah merasa terisolasi.

\section{$\mathbf{E C T}^{8}$}

Pengobatan dengan ECT diberikan pada penderita dengan toleransi bunuh diri kuat, intoleransi terhadap efek samping antidepresan atau kegagalan terapi dengan antidepresan, serta kecenderungan tidak patuh minum obat. 


\section{METODE PENELITIAN}

Penelitian ini berbentuk cross sectional (survey) yang dilaksanakan di sekolah dasar (SD) di kecamatan Wori Manado pada bulan Mei 2005 sampai dengan Juli 2005. Sampel penelitian adalah seluruh guru SD yang berada di kecamatan Wori Manado, yang disaring lagi dengan menggunakan dua kriteria, yaitu: (1) Kriteria inklusi: guru SD yang berusia dibawah 60 tahun, sudah menjadi pegawai negeri dan bersedia mengikuti penelitian. (2) Kriteria eksklusi; guru SD yang berdomisili di daerah lain dan tidak bersedia mengikuti penelitian.

Variabel penelitian dibagi atas dua kelompok besar yakni: (1) Variabel tetap: depresi dan derajat depresi, dan (2) Variabel bebas: jenis kelamin, permasalahan dalam keluarga, usia, permasalahan dalam pekerjaan, status perkawinan, jumlah anak dan status ekonomi.

Teknik penelitian yaitu dengan mendata responden yang memenuhi kriteria sampel melalui wawancara dan pengisian kuesioner Hamilton Depression Rating Scale (HDRS) yang terdiri dari 21 butir pertanyaan. Kemudian dinilai hasilnya berdasarkan skor yang diperoleh: tidak ada depresi $(<7)$, depresi ringan (7-17), depresi sedang (1824), dan depresi berat (>24). Selanjutnya dilakukan pengolahan data dan menyusunnya dalam bentuk tabel.

\section{HASIL PENELITIAN}

Berikut ini dipaparkan hasil-hasil pengolahan data penelitian yang telah dilakukan.

Tabel 1. Karakteristik variabel tetap menurut ada tidaknya depresi

\begin{tabular}{lcc}
\hline Depresi & Frekuensi & Persentase $(\%)$ \\
\hline Ada & 90 & 99 \\
Tidak ada & 1 & 1 \\
Total & 91 & 100 \\
\hline
\end{tabular}

Tabel 2. Karakteristik variabel bebas menurut jenis kelamin

\begin{tabular}{|c|c|c|c|c|c|}
\hline $\begin{array}{c}\text { Jenis } \\
\text { kelamin }\end{array}$ & $\begin{array}{r}\text { Seluruh } \\
\text { Guru SD }\end{array}$ & Ringan & $\begin{array}{c}\text { Depres } \\
\text { Ya } \\
\text { Sedang }\end{array}$ & Berat & Tidak \\
\hline Laki-laki & 26 & 8 & 11 & 6 & 1 \\
\hline Perempuan & 65 & 18 & 30 & 17 & - \\
\hline Total & 91 & 26 & 41 & 23 & 1 \\
\hline
\end{tabular}

Tabel 3. Karakteristik variabel bebas menurut usia

\begin{tabular}{cccccc}
\hline Usia & $\begin{array}{c}\text { Seluruh } \\
\text { Guru SD }\end{array}$ & \multicolumn{4}{c}{ Depresi } \\
& & Ringan & Sedang & Berat & Tidak \\
\hline $21-30$ & 6 & 1 & 5 & - & - \\
$31-40$ & 39 & 9 & 16 & 14 & - \\
$41-50$ & 22 & 7 & 11 & 4 & - \\
$51-60$ & 24 & 9 & 9 & 5 & 1 \\
Total & 91 & 26 & 41 & 23 & 1 \\
\hline
\end{tabular}


48 Jurnal Biomedik, Volume 3, Nomor 1, Maret 2011, hlm. 43-51

Tabel 4. Karakteristik variabel bebas menurut status perkawinan

\begin{tabular}{cccccc}
\hline $\begin{array}{c}\text { Status } \\
\text { Perkawinan }\end{array}$ & $\begin{array}{c}\text { Seluruh } \\
\text { Guru SD }\end{array}$ & \multicolumn{4}{c}{ Depresi } \\
& & Ra & \\
Ringan & Sedang & Berat & Tidak \\
\hline Menikah & 82 & 23 & 35 & 23 & 1 \\
Belum & 6 & 2 & 4 & - & - \\
menikah & & & & & \\
Cerai & 3 & 1 & 2 & - & - \\
Total & 91 & 26 & 41 & 23 & 1 \\
\hline
\end{tabular}

Tabel 5. Karakteristik variabel bebas menurut jumlah anak

\begin{tabular}{lccccc}
\hline \multicolumn{1}{c}{ Jumlah anak } & $\begin{array}{c}\text { Seluruh } \\
\text { Guru SD }\end{array}$ & \multicolumn{5}{c}{$\begin{array}{c}\text { Depresi } \\
\text { Ya } \\
\text { Ringan }\end{array}$} & Sedang & Berat & Tidak \\
\hline < 2 orang & 49 & 15 & 22 & 12 & - \\
$>$ 2 orang & 33 & 7 & 15 & 11 & 1 \\
Tidak ada & 3 & 2 & 1 & - & - \\
Belum & 6 & 2 & 4 & - & - \\
menikah & & & & & \\
Total & 91 & 26 & 42 & 23 & 1 \\
\hline
\end{tabular}

Tabel 6. Karakteristik variabel bebas menurut status ekonomi

\begin{tabular}{lccccc}
\hline \multirow{2}{*}{ Jumlah Gaji (Rp) } & $\begin{array}{c}\text { Seluruh } \\
\text { Guru }\end{array}$ & \multicolumn{3}{c}{ Depresi } \\
& SD & Ringan & Sedang & Berat & Tidak \\
\hline 800.000 & 31 & 6 & 15 & 10 & - \\
$800.000-1.500 .000$ & 47 & 19 & 20 & 7 & 1 \\
$1.500 .000-2.500 .000$ & 13 & 1 & 6 & 6 & - \\
Total & 91 & 26 & 41 & 23 & 1 \\
\hline
\end{tabular}

Tabel 7. Karakteristik variabel bebas menurut adanya permasalahan dalam rumah tangga

\begin{tabular}{lccccc}
\hline $\begin{array}{c}\text { Masalah } \\
\text { Rumah } \\
\text { tangga }\end{array}$ & $\begin{array}{c}\text { Seluruh } \\
\text { Guru SD }\end{array}$ & Ringan & $\begin{array}{c}\text { Depresi } \\
\text { Ya } \\
\text { Sedang }\end{array}$ & Berat & Tidak \\
\hline Ada & 55 & 19 & 21 & 15 & - \\
Tidak ada & 36 & - & - & - & 36 \\
Total & 91 & 19 & 21 & 15 & 36 \\
\hline
\end{tabular}

Tabel 8. Karakteristik variabel bebas menurut adanya permasalahan dalam pekerjaan

\begin{tabular}{lccccc}
\hline $\begin{array}{c}\text { Masalah } \\
\text { Pekerjaan }\end{array}$ & $\begin{array}{c}\text { Seluruh } \\
\text { Guru SD }\end{array}$ & \multicolumn{4}{c}{$\begin{array}{c}\text { Depresi } \\
\text { Ya }\end{array}$} \\
& & Ringan & Sedang & Berat & Tidak \\
\hline Ada & 71 & 17 & 33 & 21 & - \\
Tidak ada & 20 & - & - & - & 20 \\
Total & 91 & 17 & 33 & 21 & 20 \\
\hline
\end{tabular}


Tabel 9. Karakteristik variabel bebas menurut adanya permasalahan dalam masyarakat

\begin{tabular}{lccccc}
\hline $\begin{array}{c}\text { Masalah dalam } \\
\text { masyarakat }\end{array}$ & $\begin{array}{c}\text { Seluruh } \\
\text { Guru SD }\end{array}$ & \multicolumn{5}{c}{$\begin{array}{c}\text { Depresi } \\
\text { Ya } \\
\text { Ringan }\end{array}$} & $\begin{array}{c}\text { Sedang } \\
\text { Berat }\end{array}$ & Tidak \\
\hline Ada & 17 & 4 & 10 & 3 & - \\
Tidak ada & 74 & - & - & - & 74 \\
Total & 91 & 4 & 10 & 3 & 74 \\
\hline
\end{tabular}

\section{BAHASAN}

Berdasarkan hasil penelitian yang dapat dilihat pada Tabel 1 terhadap 91 guru SD yang menetap di Kecamatan Wori Manado, dengan menggunakan Hamilton Depression Rating Scale (HDRS) sebagai alat ukur didapatkan bahwa 90 orang (99\%) guru SD menderita depresi dengan derajat yang berbeda-beda. Hasil penelitian ini sesuai dengan yang dilakukan Pressey dkk bahwa gangguan jiwa depresi cukup sering diderita oleh guru. ${ }^{1,6,7}$

Pada Tabel 2 guru SD yang berhasil dijadikan responden dalam penelitian ini terdiri dari 26 orang guru pria dan 65 orang guru wanita. Berdasarkan hasil wawancara, didapatkan bahwa guru wanita lebih banyak menderita depresi daripada guru pria. Hal ini dikarenakan disamping menjalankan profesinya, guru wanita juga masih mempunyai tugas di rumah mengurus keluarga. Kaplan dkk (1994) mengemukakan bahwa prevalensi depresi pada perempuan biasanya dua kali atau lebih dibandingkan dengan laki - laki. ${ }^{15}$

Pada Tabel 3 didapatkan bahwa guru SD yang paling banyak menderita depresi berada dalam kelompok usia 31-40 tahun, yaitu sebanyak 39 orang. Menurut Wilkinson serangan depresi terbanyak terdapat pada kelompok usia 35-45 tahun. ${ }^{1}$ Hal ini terjadi karena pada usia-usia ini mereka harus menghadapi berbagai krisis-krisis yang ada dalam keluarga, masyarakat dan pekerjaannya.

Dari hasil penelitian pada Tabel 4 didapatkan bahwa yang paling banyak menderita depresi adalah mereka yang sudah menikah yaitu sebanyak 81 orang. Menurut Wilkinson bahwa mereka yang sudah menikah kurang menderita depresi dibandingkan yang belum menikah. ${ }^{1}$ Tapi pada penelitian ini diperoleh depresi lebih banyak diderita oleh guru SD yang sudah menikah. Hal ini mungkin disebabkan oleh jumlah sampel penelitian ini lebih banyak guru-guru yang sudah menikah, yang mempunyai tanggungan hidup lebih banyak, misalnya anak-anak mereka harus melanjutkan sekolah sedangkan gaji guru tidak mencukupi.

Tabel 5 memperlihatkan bahwa yang terbanyak menderita depresi guru SD yang memiliki anak kurang dari dua orang, yaitu sebanyak 49 orang. Sedangkan dari guru SD yang memiliki anak lebih dari dua orang hanya sebanyak 33 orang. Berdasarkan hasil wawancara, guru SD yang memiliki anak lebih dari dua orang biaya hidupnya tidak terlalu besar karena anak-anaknya masih balita dan belum sekolah. Sedangkan guru SD yang memiliki anak kurang dari dua orang, biaya hidup untuk anak tersebut besar dikarenakan melanjutkan pendidikan sampai perguruan tinggi. Menurut Wilkinson bahwa bertambahnya anggota keluarga dapat menjadi pemicu timbulnya depresi. Hasil penelitian ini berbeda dengan penelitian Wikinson. Hal ini mungkin disebabkan oleh jumlah sampel pada penelitian ini lebih banyak guru SD yang memiliki anak kurang dari dua orang.

Pada Tabel 6 didapatkan bahwa guru SD yang berpenghasilan antara Rp. 800.000 sampai dengan Rp.1.500.000 paling banyak menderita depresi, yaitu sebanyak 49 orang. Guru SD yang penghasilannya Rp. 800.000 juga mengalami depresi yaitu sebanyak 30 orang dan guru SD yang penghasilannya Rp.1.000.000 sampai dengan Rp. 2.000.000 sebanyak 12 orang. Berdasarkan wawancara dengan guru-guru, hampir semua dililit hutang dikarenakan gaji guru yang tidak 
mencapai standar yang layak untuk hidup minimal setiap bulan bersama keluarganya. Hal ini sesuai dengan teori bahwa tingkat ekonomi merupakan salah satu faktor sosiogenik yang merupakan sumber penyebab gangguan jiwa depresi.

Tabel 7 memperlihatkan bahwa 50 orang guru SD yang mempunyai permasalahannya dalam rumah tangga menderita depresi. Menurut Priest (1994) bahwa keluarga bisa menjadi sumber utama depresi. Berdasarkan hasil wawancara, masalah-masalah yang sering terjadi dalam rumah tangga adalah seperti kerepotan dalam mengurus rumah tangga yang tidak mempunyai pembantu, tuntutan anak yang tidak dapat dipenuhi oleh orang tua, banyaknya pengeluaran yang tidak terduga dan keperluan mendadak lain-lain dalam rumah tangga.

Pada Tabel 8 didapatkan bahwa 71 orang guru SD yang mempunyai permasalahan dalam pekerjaan menderita depresi. Kepuasan kerja pada hakekatnya apabila telah terpenuhinya setiap kebutuhan-kebutuhan yang diinginkan oleh manusia, mengacu pada teori Maslow mengenai lima kebutuhan dasar manusia dan urutan penggolongannya didasarkan pada kekuatan potensi dan desakan urgensinya.

Tabel 9 memperlihatkan bahwa 17 orang guru SD yang mempunyai permasalahan dalam masyarakat mengalami depresi. Hal ini dikarenakan masyarakat terlalu banyak membebankan tugas mendidik anak pada mereka sehingga sedikit saja kenakalan yang dibuat anak-anak, guru yang dipersalahkan. Menurut Wilkinson bahwa akibat tekanan pekerjaan yang banyak dapat mengganggu hubungan antar sesama, dan keadaan inilah yang dapat menjadi sumber depresi. ${ }^{1}$

\section{SIMPULAN}

Disadari bahwa penelitian ini masih banyak kekurangan baik kemampuan peneliti maupun subyek penelitian. Namun demikian ada beberapa hal yang dapat diambil dari penelitian ini adalah :

1. Depresi ditemukan $99 \%$ pada guru SD yang mengajar di Kecamatan Wori Manado.

2. Penderita depresi terbanyak ditemukan pada jenis kelamin perempuan dibandingkan laki-laki.

3. Penderita depresi banyak ditemukan pada usia 31-40 tahun

4. Penderita depresi banyak ditemukan pada mereka yang sudah menikah.

5. Kebutuhan hidup berupa gaji yang tidak maksimal pada guru SD menyebabkan depresi berat.

\section{SARAN}

1. Perlu adanya penelitian yang lebih mendalam terhadap faktor-faktor penyebab depresi Guru SD dan cara mengatasinya oleh pihak yang berwenang terutama menyangkut masalah kesejahteraan guru.

2. Pemberian dukungan kerja kepada guru SD dari lingkungan keluarga dan sosial.

\section{DAFTAR PUSTAKA}

1. Wilkinson G. Depresi. Jakarta: ARCAN, 1992.

2. Priest R. Bagaimana cara mencegah dan mengatasi stres dan depresi. Semarang: Dahara prize, 1994.

3. Prawirohadikusumo S. Depresi dan stroke. Berita Kedokteran Masyarakat. [Supp] XV(2), 1999.

4. Hardiman A, Hanafi. Psikodinamika depresi. Indonesian Psychiatric Quarterly. 1998;21(2):19-26.

5. Kusumanto SR, Iskandar Y. Psikiatri Biologik: Depresi tersamar dalam praktek umum. Jakarta: Yayasan Dharma Graha, 1987.

6. Sahertian, Piet A. Profil Pendidik Profesional. Yogyakarta: Andi Offset, 1994.

7. Sahertian, Piet A, Ida AA, Sahertian. Supervisi Pendidikan dalam Rangka Program In-service Education. Jakarta: Rineka Cipta, 1990.

8. Laksmana G. Depresi pada usia lanjut. Medika. 1996;7(22):544.

9. Soejono P. Penanggulangan Praktis Gangguan Depresi. Yogyakarta: Bagian Psikiatri UGM, 1990. 
10. Dimascio A, Goldberg H. Emotional Disorders. An outline guide to diagnosis and pharmacological treatment (Third Edition). Oradell: Medical Economics Company, 1981.

11. Wiwie SM, Nasrun S. Pengelolaan depresi pada usia lanjut. In: Soejono $\mathrm{CZ}$, Setiawati S, Wiwie SM, Silaswati S, editor. Pedoman Pengelolaan Kesehatan Pasien Geriatri. Jakarta: Pusat Pengembangan dan Penerbitan Bag IPD FKUI, 1999; p.60-76.

12. Setjipto, Hoedijono S. Depresi pada Lansia. Surabaya: Lab/SMF IKJ FK Unair, 1999; p.1-23.

13. Dahl RE. Brent D. Affective Disorders and Suicide (Twentieth Edition). California: Prentice Hall International inc, 1996.

14. Relis VI. Mood disorders. In: Lewis M. penyunting. Child and Adolescent Psychiatry. Philadelpia: Williams dan Wilkins, 1991; p.652-62.

15. Kaplan HI, Saddock BJ, Grebh JA. Si- nopsis Psikiatri (Edisi ke-7). Terjemahan. Jakarta: Binarupa Aksara, 1997; p.809-17.

16. Iskandar Y. Prevensi dan terapi gangguan depresi. MKI. 1994;2(44):67.

17. Departemen Pendidikan Nasional RI. Pedoman pembinaan karir tenaga kependidikan. (The ICD-10 classification of mental and behavioural disorders: diagnostic criteria for research. Geneva: WHO, 1992). Jakarta, 2001.

18. American Psychiatric Assoaciation. Diagnostic dan statistical manual of mental disorder (Third Edition) Rev ed. Washington DC: American Psychiatric Press, 1987.

19. Departemen Kesehatan RI, Direktorat Jenderal Pelayanan Medik. Pedoman Penggolongan Diagnosis Gangguan Jiwa di Indonesia III. Jakarta, 1993.

20. Milhorn HT. Chemical Dependence: diagnosis, treatment and prevention. New York: Springer-Verlag, 1990. 